\title{
Model Pengukuran Proses Bisnis CRM Berbasis eTom dan IT-IL
}

\section{A Measurement Model of CRM Business Based on eTom and IT-IL}

\author{
Lihardo Ranjaliba Saragih, Gendut Suprayitno, Dahmir Dahlan \\ Institut Sains dan Teknologi Nasional \\ Jl. Moch Kahfi II, Jakarta 12640, Indonesia \\ Email: ranjaliba@gmail.com; gendut.suprayitno@gmail.com; dddkamang@yahoo.com
}

\begin{abstract}
Nowadays Telecom Company doing business model transformation through Manage services, to reduce cost. Telecommunications companies obviously attached to cutting-edge technology and capital-intensive, therefore needs a different approach in Order to remain competitiveness, not just a simple outsourcing. It made paradigm of outsourcing in global Telecommunications industry changed, in term of Manage service.Company realizes that Manage service is complicated defined, even more complicate executed, so its necessary to have a Maturity level measurement in activities or business Processes scale that will be outsourced. This study is conducted to examine business Processes Maturity level that build Manage services, towards company business model rearrangement.Researchers using the eTOM framework and IT-IL in measuring business unit "Customer Relationship Management - Customer Care" which will apply Manage service. Study results identification aspects that related to potential Manage services outsourced, governance restructuring advice according to reference business Processes Maturity level, and provide appropriate policy recommendations
\end{abstract}

Keywords: Business Process Maturity Level, eTOM, IT-IL, CRM - Customer Care

\begin{abstract}
Abstrak
Saat ini perusahaan Telekomunikasi melakukan transformasi model bisnis melalui Manage service, untuk mengurangi beban biaya perusahaan. Perusahaan telekomunikasi sangat melekat dengan teknologi mutakhir dan padat modal, maka transformasi perlu dilakukan dengan pendekatan khusus sehingga dapat mempertahankan daya saing, bukan sekedar outsourcing karyawan umumnya. Hal ini kemudian mengubah paradigma outsourcing dalam industri telekomunikasi global dalam sebuah istilah Manage service.Perusahaan menyadari bahwa Manage service ternyata rumit didefinisikan apalagi dieksekusi, sehingga perlu dilakukan pengukuran tingkat kematangan dalam skala aktivitas atau proses bisnis yang akan dialihdayakan. Penelitian dilakukan untuk mengukur tingkat kematangan proses bisnis dalam Manage services, menghasilkan penataan ulang model bisnis perusahaan.Peneliti menggunakan framework eTOM dan IT-IL dalam mengukur unit bisnis "Customer Relationship Management - Customer Care" yang akan menerapkan Manage service. Hasil studi adalah berbagai aspek identifikasi terkait dengan layanan potensial outsourcing yang dikelola, saran restrukturisasi tata kelola sesuai dengan referensi tingkat kematangan, dan memberikan rekomendasi kebijakan yang tepat.
\end{abstract}

Kata kunci: Tingkat Kematangan Proses Bisnis, eTOM, IT-IL, CRM - Customer Care

\section{Pendahuluan}

Perusahaan melakukan transformasi model bisnis mereka dengan beralih menggunakan Manage service. Karena penguasaan pasarnya yang tinggi di dalam dan maupun luar negeri, bagi para vendor Manage service dan penyedia jasa produk telekomunikasi (operator) percaya bahwa pasar Manage service adalah menjanjikan bagi masa depan industri yang sangat kompetitif. Bila dilihat

Received:23 November 2014; Revised: 22 Desember 2014; Accepted: 27 Januari 2015 ; Published online: 30 April 2015 C2014 INKOM 2014/14-NO399 kembali pada bentuk bisnis perusahaan yang telah berjalan dan dalam posisi yang sudah stabil, maka proses untuk dapat merubah/merombak kembali dengan menempatkan system Manage service di dalamnya adalah rumit untuk didefinisikan bahkan lebih jauh lagi untuk dijalankan.

Peneliti melakukan analisis dan sintesis symptom berawal dari adanya fenomena-fenomena tersebut diatas, dengan mendefinisikan proses bisnis dan analisis aktivitas perusahaan yang lengkap, efektif dan efisien. Menentukan pola Manage service yang tepat melalui kerangka 
standar proses bisnis perusahaan telekomunikasi melalui TMF (Telecommunication Modelling Framework) menggunakan eTOM dan IT-IL, setelah itu perlu mengelola vendor sebagai pihak ketiga sebagai perencana dan penyelenggara layanan tersebut, sehingga pengembangan layanan dapat berjalan efektif dan efisien. Pada akhirnya, yang paling utama adalah bagaimana merekomendasikan strategi untuk menjaga atau mencapai keunggulan kompetitif perusahaan.

Berdasarkan konsep symptom, analisis dan akar permasalahan yang terkait, maka penulis merumuskan permasalahan yang dihadapi dalam penelitian yang dilakukan adalah berikut: (1) identifikasi faktor/aspek yang potensial untuk dialihdayakan terkait dengan Manage service; (2) restrukturisasi/rancang tata kelola Manage service; (3) analisis pengaruh framework eTOM dan IT-IL terhadap desain Manage service; (4) mengukur tingkat kematangan proses bisnis.

Tujuan penyusunan untuk membantu unsur organisasi perusahaan yang bergerak pada bidang Jasa Telekomunikasi. Dari sisi bisnis, perusahaan tersebut diharapkan dapat bertahan dan makin maju saat tingginya tingkat persaingan antar operator telekomunikasi, dimana sangat penting untuk mengalihdayakan proses bisnis mereka dengan tepat dan menentukan tata kelola proses bisnis Manage service yang paling tepat. Dari sisi produk dan teknologi, dalam industri telekomunikasi para perusahaan saling berpacu dalam menggunakan teknologi mutakhir, namun tetap mampu menjaga kualitas dan aliran keuangan yang baik sebagai badan usaha yang profit.

Penelitian diharapkan mampu mengidentifikasi faktor potensial untuk dialihdayakan dengan Manage service, mengacu pada kerangka yang standar pada industri telekomunikasi yaitu eTOM dan IT-IL. Perusahaan tersebut melakukan restrukturisasi pada unit bisnis CRM-Customer Care merujuk pada proses bisnis eTOM. Proses bisnis perusahaan yang perlu direstrukturisasi akan diteliti dengan melakukan pengambilan data langsung pada staf terkait, untuk dapat dilihat pengaruh framework yang menjadi acuan terhadap design Manage servis yang akan diterapkan. Data yang didapatkan sangat berguna untuk mengukur tingkat kematangan proses bisnis saat ini pada unit bisnis terkait. Berdasarkan acuan kerangka eTOM yang digunakan oleh peneliti maka dapat dipetakan antara kematangan proses saat ini dengan proses bisnis yang diinginkan sesuai standar eTOM. Akhir dari penelitian ini didapatkan nilai kesenjangan, yang kemudian akan dapat dianalisa dan berguna sebagai saran atau rekomendasi bagi proses bisnis yang telah berjalan, sehingga menjadi lebih baik atau optimal.

\section{Landasan Teori \\ 2.1 Perusahaan Telekomunikasi Terhadap Kerangka eTOM dan IT-IL}

eTOM merupakan framework yang diterima secara luas untuk proses bisnis pada industri informasi, komunikasi dan hiburan [12], merupakan framework standar yang didefinisikan dalam area proses bisnis telekomunikasi [13], dan saat ini para penyedia layanan ICT, terutama industri Telecom sangat giat menggunakan eTOM untuk mengembangkan, delivery dan Support servis endto-end pada perusahan mereka [4], [14].

Framework eTOM dan IT-IL saling melengkapi, eTOM menangkap Kebutuhan Proses Bisnis SP dan membentuk model proses sesuai parameter kerangka yang telah dimiliki oleh eTOM. Model tsb menghasilkan berbagai aliran proses sesuai model eTOM, dan merepresentasikan solusi yang dapat berjalan untuk skenario bisnis tertentu. Sedangkan IT-IL mendefinisikan IT good practise yang diperlukan, kemudian mengelolanya menjadi suatu model pada area yang sebelumnya telah didefinisikan melalui eTOM, misalkan: IT service delivery, Support, dan lain-lain.

\section{2 eTOM v12}

eTOM adalah suatu kerangka proses bisnis yang merupakan singkatan dari Enhance Telecom Operations Map yang banyak diterapkan dan digunakan untuk menyediakan layanan end-to-end pada industry telekomunikasi[4]. eTOM sebagai standar untuk Telecommunications Management Network, berdasarkan ITU-T Recommendation M.3050.2. eTOM dikembangkan mulai awal 90an berdasarkan input dari berbagai Service Provider untuk menghasilkan model proses bisnis. eTOM adalah standar proses bisnis yang paling banyak digunakan pada industri telekomunikasi[14].

Kerangka/framework Enhanced Telecom Operation Map eTOM, dikeluarkan oleh TeleManagement Forum (TM Forum) dan itSMF. Konsep yang perlu selalu diingat bahwa eTOM tidak menunjukkan isu strategis atau jawaban dari siapa seharusnya Customer yang layak menjadi target dari service provider, market segment seperti apa yang seharusnya dilayani service provider, apa saja visi, misi service provider tersebut dll, akan tetapi berfungsi sebagai kerangka proses bisnis dan referensi, untuk memandu pengembangan dan manajemen perusahaan telekomunikasi. Terdapat tiga proses utama pada eTOM: "Strategy, 


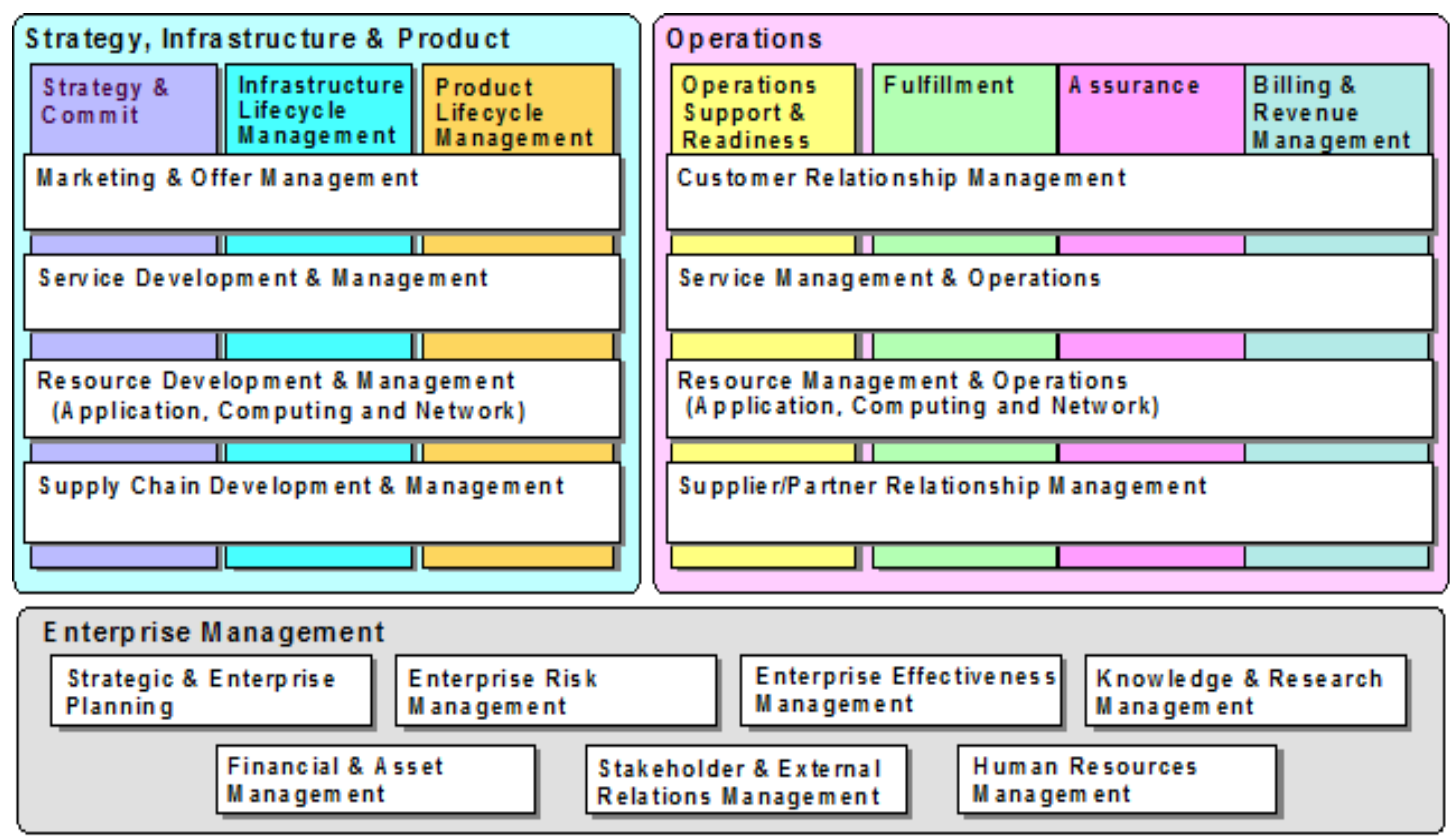

Gambar 1. eTOM level-0 [11].

Infrastructure \& Product", "Operation", dan "Enterprise Management"

Secara pendefinisian proses bisnis, eTOM terdiri dari empat level Level-0, Level-1, Level-2 dan Level-3 pada kerangkat eTOM, dimana tiap tingkat hirarki membungkus kelompok proses lebih detail di tingkat berikutnya. Pada baris/tingkat atas adalah kegiatan pelanggan (seperti pemasaran yang dihadapi), dan kemudian baris/tingkat bawah adalah supplier dan aktivitas pendukung. Gambar 1 adalah eTOM level 0, yaitu keseluruhan framework eTOM pada hierarki proses bisnis teratas atau paling luas.

\subsection{IT-IL (Information Technology Infrastructure Library) v3}

Information Technology Infrastructure Library ITIL, dikeluarkan oleh UK Office of Government Commerce(OGC), yang terdiri lima volume layanan: Strategy, Design, Transition, Operation, Continual Improvement, dimana IT-IL mampu mengelola semua kegiatan dan antarmuka Manage service, dengan menyediakan tata kelola layanan.

Dalam organisasi IT, IT-IL berfungsi Referensi manajemen bisnis layanan IT, yang mampu memfokuskan pada penyelarasan layanan(service) dan pendukung(Support) layanan tersebut. IT-IL dapat Menjadikan layanan IT lebih efisien untuk berkolaborasi di seluruh lifecycle organisasi sesuai Gambar 2. Dengan IT-IL Kebutuhan pelanggan dapat lebih efektif untuk diperoleh/dikenali dan dikelola, IT-IL dapat Menjadikan bisnis layanan pendukung IT berjalan selaras. Melalui IT-IL para pengambil kebijakan dapat proaktif mengambil kendali perubahan organisasi.

\subsection{Kerjasama Framework eTOM dan IT-IL}

Proses eTOM dan ITIL dapat saling terkait, dan mampu memberikan informasi mengenai pemetaan dari satu tampilan ke tampilan proses yang lain, melalui TMF yaitu sebuah Panduan Interpreter untuk praktisi eTOM dan ITIL [4].

Model pada Gambar 3 menghasilkan berbagai aliran proses sesuai model eTOM, merepresentasikan solusi yang dapat berjalan pada skenario bisnis. Di sebelah kiri: eTOM menangkap Kebutuhan Proses Bisnis SP dan membentuk model proses. Di tengah: IT-IL mendefinisikan IT good practise tingkat kematangan yang diperlukan, mengelolanya menjadi suatu model pada area: IT Service Delivery, Support, dalam tesis ini yaitu CRM-CC. Di sebelah kanan: eTOM dan IT-IL yang saling melengkapi; menjadi aliran bisnis yang menampilkan layanan good practice.

\subsection{IT-IL Maturity Level}

Untuk mendesain proses bisnis Manage service, perlu mereferensi pada IT-IL yang spesifik pada volume design, yaitu bagaimana mengetahui tingkat kematangan proses bisnis pada saat ini untuk digantikan oleh Manage service, melalui konsep IT-IL Maturity Level. 


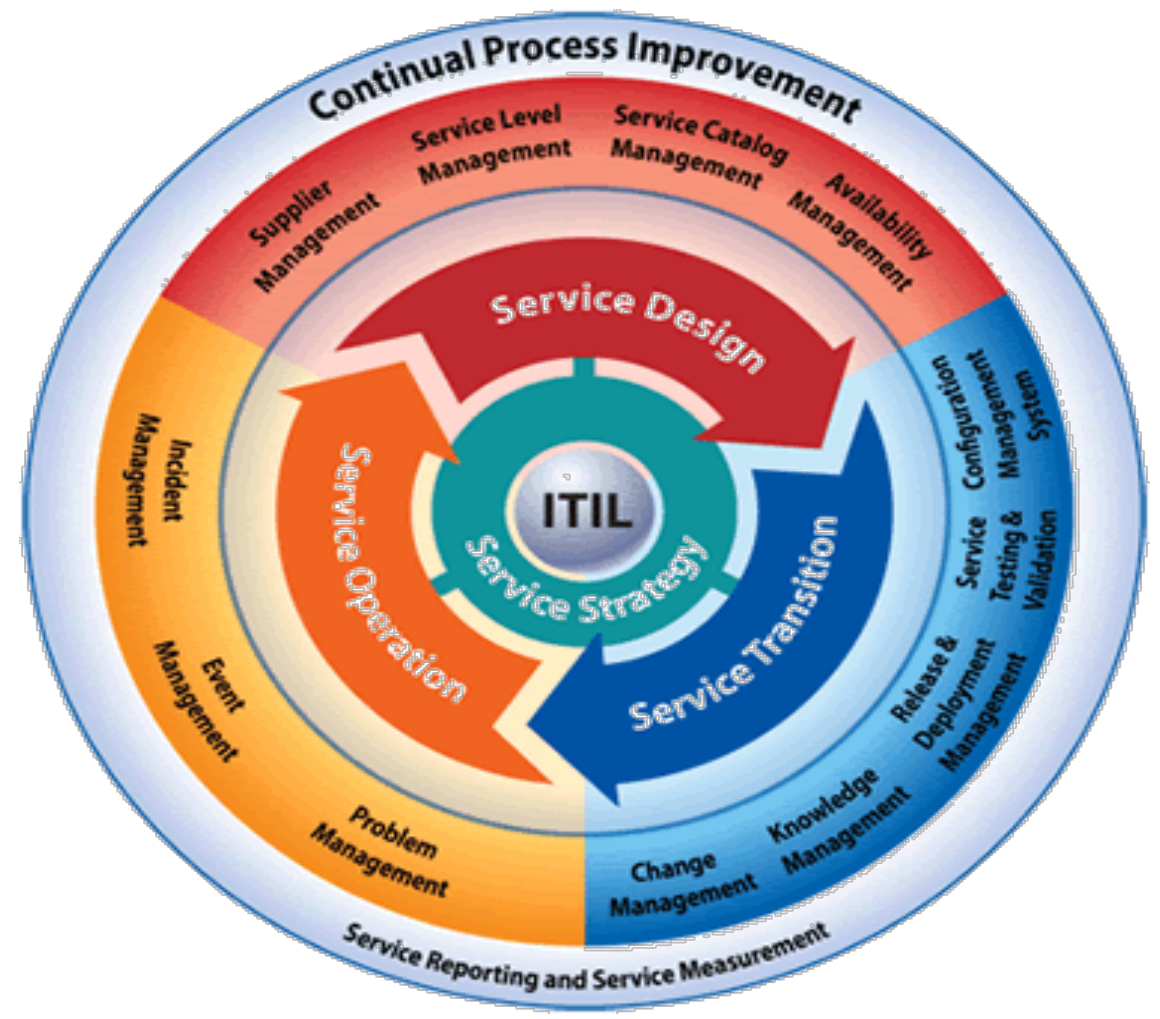

Gambar 2. IT-IL versi 3 [7].
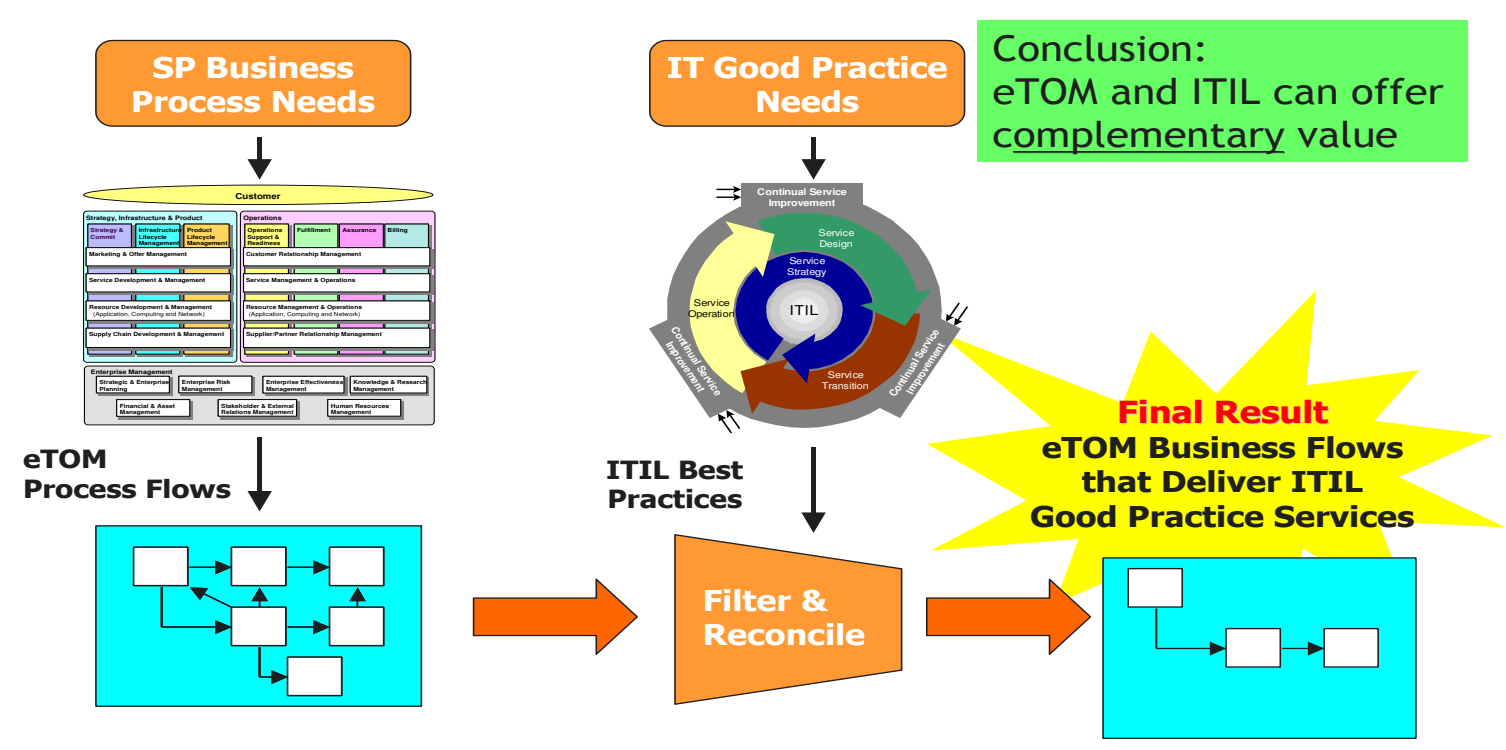

Gambar 3. ITIL and eTOM - working together (TR143_Building_Bridges-ITIL_and_eTOM - [11].

\section{Metodologi Penelitian}

\subsection{Kerangka Berfikir Penelitian}

eTOM meneyediakan kerangka proses bisnis yang mendukung penelitian ini, yang sudah mendukung secara lengkap proses bisnis pada unit bisnis Customer Relationship Management (CRM) Customer Care, sehingga eTOM menjadi nilai input/masukan. Pada kerangka eTOM dipilih proses bisnis hingga level 4 secara detail, hal ini sebagai input awal penelitian, adapun eTOM sudah member referensi pada kerangka IT-IL service level Management level 2 sebagai dasar dari manajemen efektif perusahaan. Proses digunakan IT-IL good practice, dengan spesifikasi IT-IL service design. Mengukur tingkat kematangan proses bisnis yang diperoleh melalui 


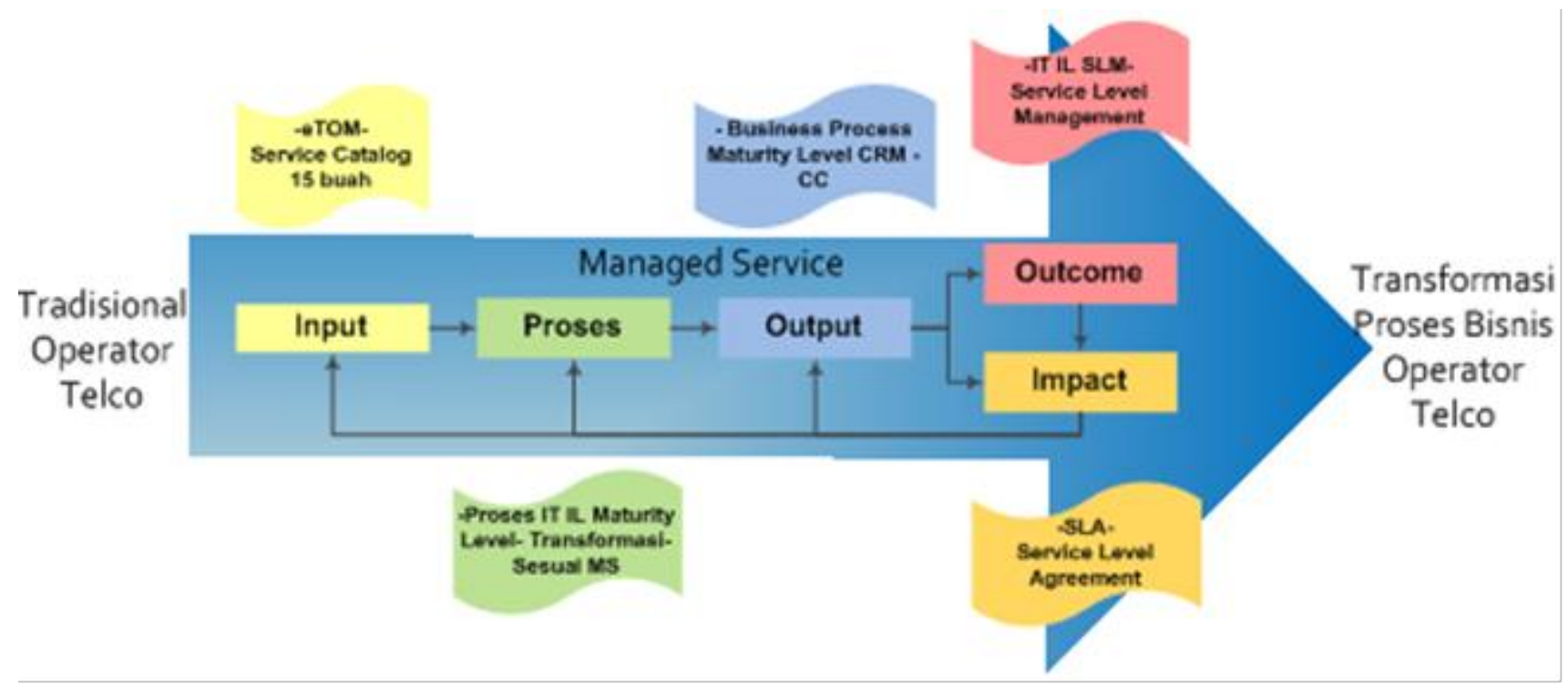

Gambar 4. Kerangka Berfikir Umum Penelitian.

proses sebelumnya (eTOM), kemudian menggunakan teknik IT-IL Maturity level menjadikan proses-proses tersebut menjadi terukur tingkat kematangannya pada unit prosedural dan teknis operasional. Output yang diharapkan ialah nilai kematangan tiap proses bisnis eTOM yang relevan pada unit CRM- Customer Care. Penelitian dilakukan dengan menyebarkan kuesioner dan borang untuk diperoleh kondisi teknis pada level operasional staff sehari-hari, berdasarkan hasil dari masing-masing populasi maka akan didapatkan nilai tingkat kematangan yang objektf dari proses bisnis yang telah berlangsung pada saat ini. Nilai kematangan yang didapatkan pada saat ini dianggap sudah merepresentasikan kondisi kematangan yang sesungguhnya, untuk dianlisa pada tahap selanjutnya baik-buruk, maju-mundur, dan sudah maju-mundur nya tingkat pemahaman, praktik, dan kepuasan pelanggan secara langsung pada level teknis. Outcome penelitian adalah bagaimana mendefinisikan Manage service melalui service level Management, melalui pemanfaatan hasil perhitungan level kematangan dan kerangka eTOM yang menjadi acuan terlengkap pada industry telekomunikasi saat ini. Service level Management menghendaki adanya kondisi kesepakatan yang tepat, berdaya guna dan menguntungkan dari sisi operasional saat dijalankan pada unit bisnis CRMCustomer Care. Seteleh mendefinisikan service level Management, kemudian eTOM dan IT-IL yang telah menghasilkan tingkat kematangan proses bisnis saat ini, melalui pemetaan pada proses bisnis Customer Relationship Management sesuai dan diproses melalui service design bestpractice IT-IL, diperoleh kesepakatan SLA (Service License Agreement) dan KPI (Key Performance Indicator) pada tiap proses bisnis yang dijalankan. SLA dan KPI danberbagai data sumber referensi diataranya mengetahui kondisi proses bisnis saat ini melalui perhitungan level kematangan eTOM saat ini, dan juga service level Management sebagai definisi dari proses baru yang berisi manajemen proses bisnis baru Manage service yang bisa diterapkan pada perusahaan operator. Dilakukan monitoring dan evaluasi regular terhadap pencapaian KPI yang dikerjakan oleh vendor, hal ini berpengaruh atau impact pada kinerja dan secara langsung keuntungan perusahaan operator karena merupakan layanan yang dirasakan langsung oleh pelanggan pada sisi akhir.

\subsection{Tahapan Penelitian}

Fase 0: Studi Literatur. Aktivitas: Melakukan kajian pustaka pada teori eTOM dan ITIL sebagai dasar framework pendukung pada penelitian ini.

Fase 1: Identifikasi komponen Framework. Aktivitas: Melakukan dekomposisi Bisnis Proses (BP) Customer Relationship Management pada Framework eTOM, dan menyesuaikan pada service catalog MS.

Fase 2: Mapping ke BP Customer Care, pd aktivitas Manage service. Aktivitas: Penurunan Bisnis Proses eTOM Customer Relationship 
Management (CRM), pada bagian Customer Care untuk Manage Service.

Fase 3: Borang dan Kuesioner. Aktivitas: Perancanganan Borang dan Kuesioner sesuai konsep akademis sebagai alat ukur, dan melakukan distribusi untuk mendapatkan data penelitian.

Fase 4: Pengukuran IT-IL Maturity. Aktivitas: Menggunakan teknik Self Assessment. Ini memberikan indikasi yang berguna dari pandangan praktisi IT pada seberapa baik proses telah dikerahkan dan dieksekusi, melalui kuesioner.

Fase 5: IT IL - Service Level Management SLA and KPI. Aktivitas: Menyediakan laporan hasil kematangan proses bisnis dan saran yang diberikan terhadap perusahaan. Saran yang diberikan berupa proses bisnis yang kurang optimal atau saran akan proses bisnis baru.

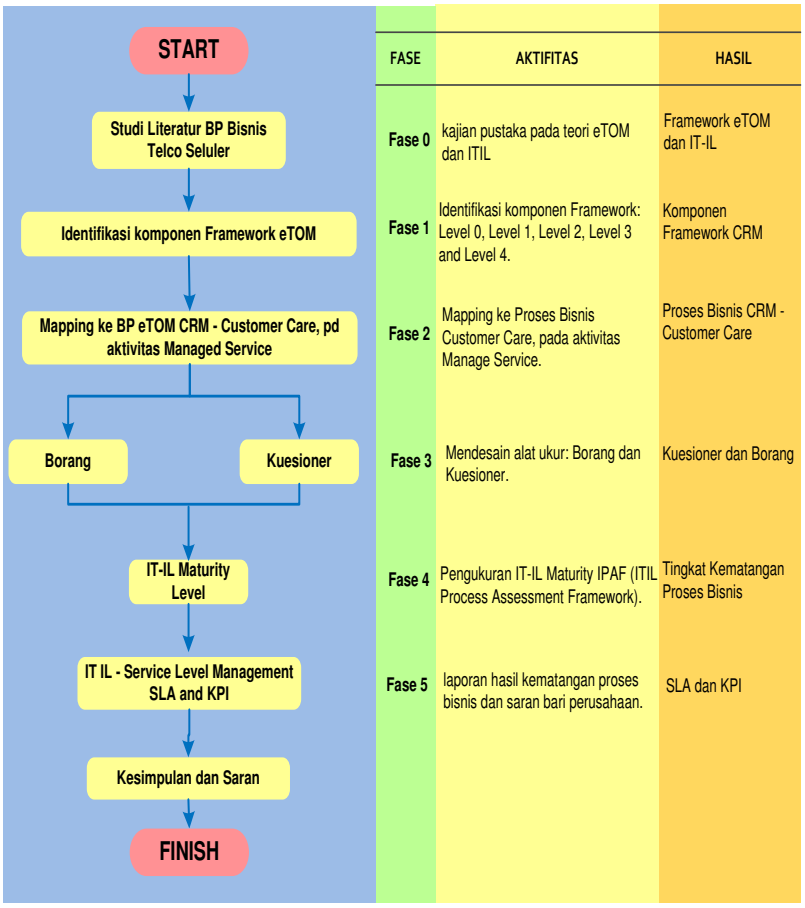

Gambar 5. Tahapan Penelitian

\section{Pelaksanaan Penelitian dan Pengolahan Data}

\subsection{Fase 1 Penelitian}

Kotak kuning adalah framework eTOM menyeluruh, penelitian ini mendekomposisikan CRM berdasarkan pada kotak merah, dimana Penurunan Level 0 - Komponen Framework CRM. Urutan tingkat kerangka eTOM bernama: 1 . eTOM Operations Horizontal Functional Process Grouping.
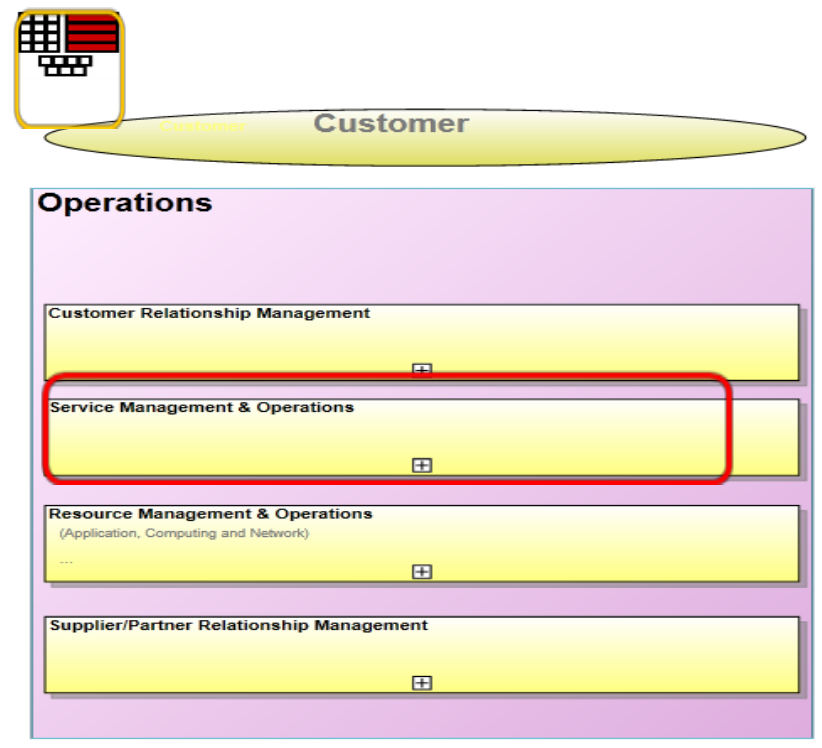

Gambar 6. Penurunan Level 0, identifikasi komponen level framework [11]

Menuju proses bisnis yang lebih detail dari operation CRM, maka dilakukan dekomposisi pada kotak merah pada gambar di bawah, dimana Penurunan bernama: Level 1 - Komponen Framework CRM.

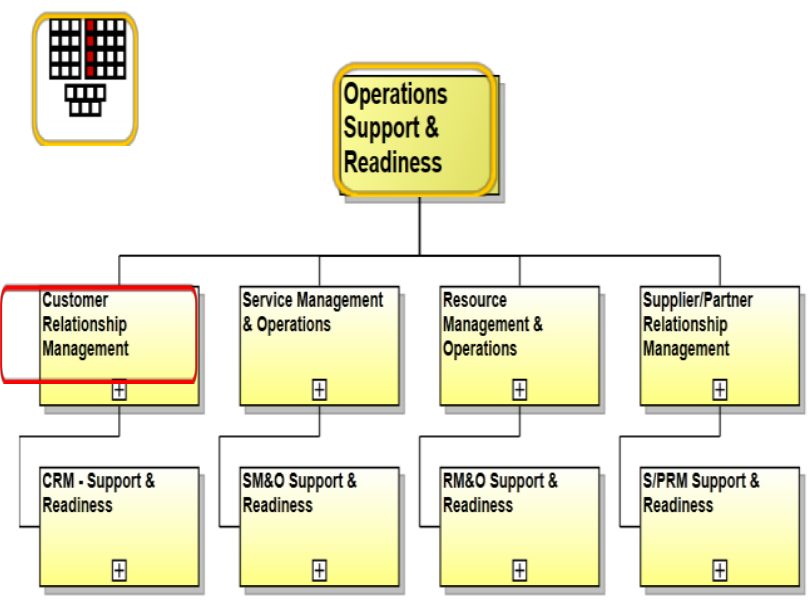

Gambar 7. Penurunan Level 1, identifikasi komponen level framework [11]

Penurunan Level 2 - Komponen Framework operations Support \& Readiness, memiliki 8 subproses, maka dekomposisi pada urutan tingkat kerangka eTOM bernama: 1.1.1 Customer Relationship Management. 


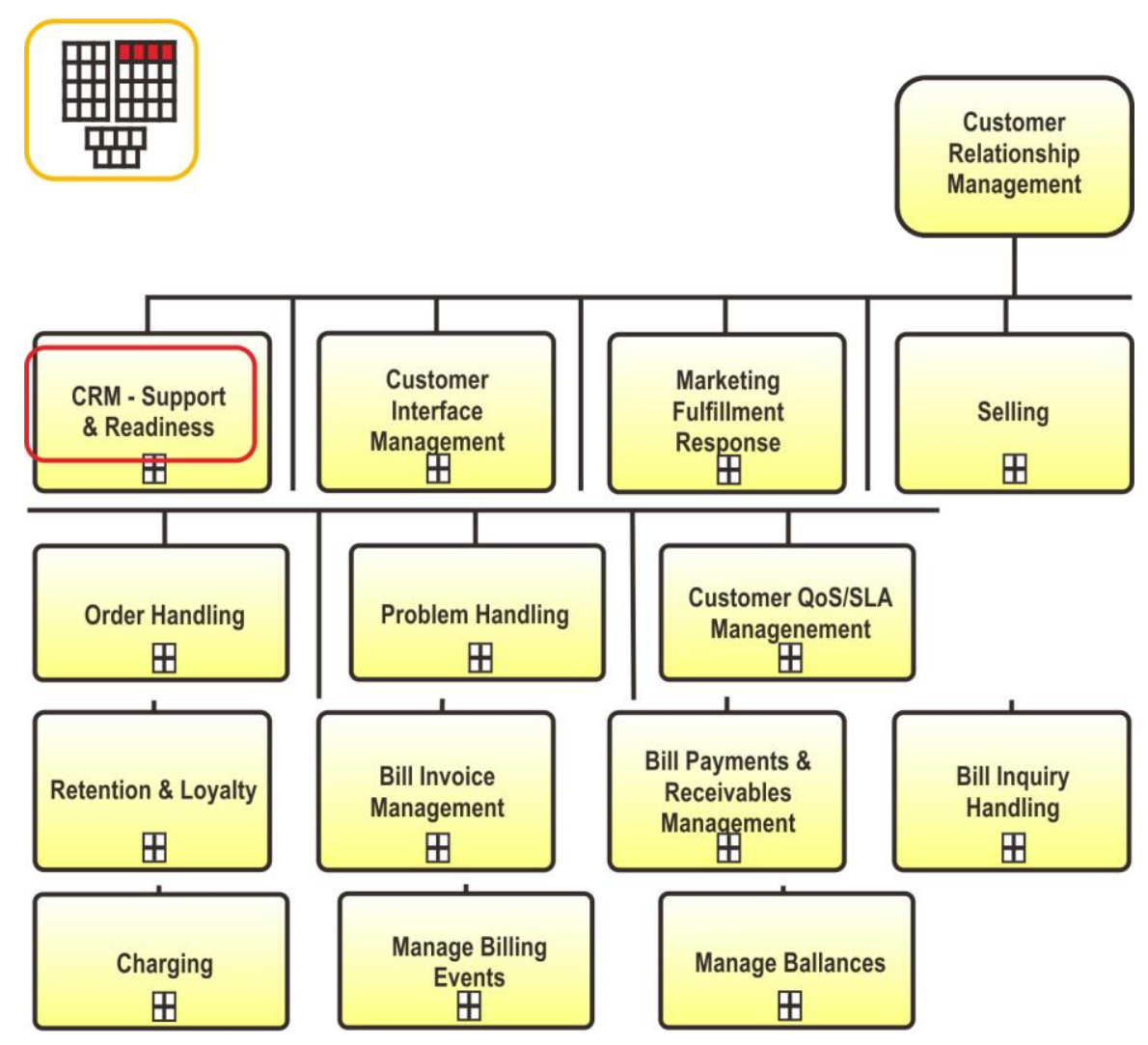

Gambar 8. Penurunan Level 2, identifikasi komponen level framework [11]

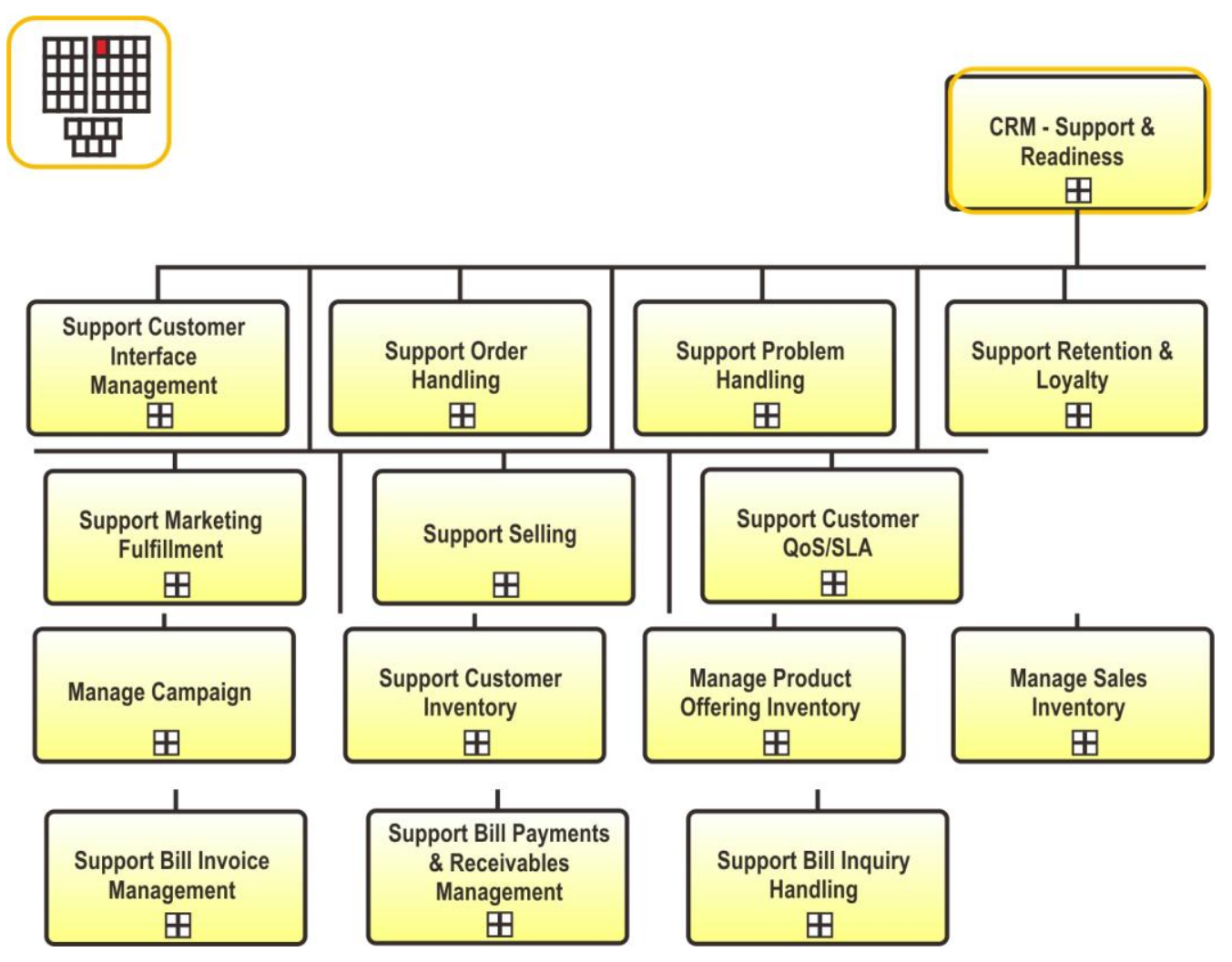

Gambar 9. Penurunan Level 3, identifikasi komponen level framework [11]. 
Penurunan Level 3 - Komponen Framework Customer Relationship Management, memiliki 14 subproses, maka dekomposisi pada urutan tingkat kerangka eTOM ini bernama: 1.1.1.1 CRM Support \& Readiness.

Penurunan Level 4 - Komponen Framework pada proses bisnis CRM-Support \& Readiness level 3 memiliki 15 subproses: 1.1.1.1.1 Support Customer Interface Mgt, 1.1.1.1.2 Support Order Handling, 1.1.1.1.3 Support Problem Handling, 1.1.1.1.4 Support Billing \& Collections, 1.1.1.1.5 Support Retention \& Loyalty, 1.1.1.1.6 Support Marketing Fulfillment, 1.1.1.1.7 Support Selling, 1.1.1.1.8 Support Customer QoS/SLA, 1.1.1.1.9 Manage Campaign, 1.1.1.1.10 Manage Customer Inventory, 1.1.1.1.11 Manage Product Offering Inventory, 1.1.1.1.12 Manage Sales Inventory, 1.1.1.1.13 Support Bill Invoice Mgt, 1.1.1.1.14 Support Bill Payments\&Receivables Mgt, 1.1.1.1.15 Support Bill Inquiry Handling

\subsection{Fase 2 Penelitian}

Mapping ke Proses Bisnis Customer Care, pada aktivitas Manage service. Penurunan Proses Bisnis eTOM Customer Relationship Management (CRM), sesuai pada criteria unit bisnis Customer Care Manage service.

Tabel 1. Penentuan Proses Bisnis, kriteria Customer Care

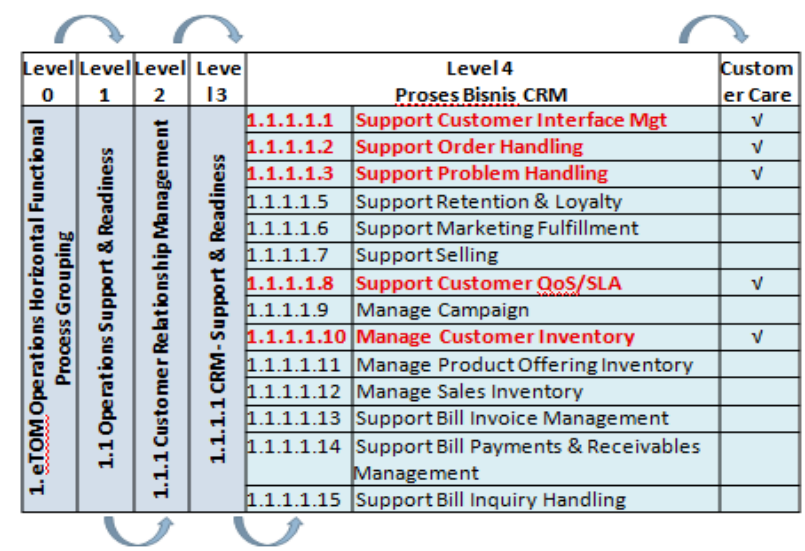

Dekomposisi pada tahap ini menghasilkan 5 proses bisnis sebagai berikut: L4 :1.1.1.1.1 Support Customer Interface Mgt, L4 : 1.1.1.1.2 Support Order Handling, L4 : 1.1.1.1.3 Support Problem Handling, L4 : 1.1.1.1.8 Support Customer QoS/SLA, L4 : 1.1.1.1.10 Manage Customer Inventory

\subsection{Fase 3 Penelitian}

Mendesain alat ukur: Borang dan Kuesioner. Teknik purposive random sampling yaitu pengambilan sampel untuk tujuan dan dengan syarat-syarat tertentu [15].

Alat ukur Kuesioner: Maturity Level pada kuesioner berdasarkan kriteria level IT SM Benchmark, agar sesuai tujuan yang ingin dicapai oleh konteks proses bisnis eTOM, yaitu Framework Process Report 12.5.0. Alat Ukur borang: Mengkontruksikan mengenai organisasi, kejadian dan tuntutan pada proses bisnis.

\subsection{Fase 4 Penelitian}

Pengukuran IT-IL bersumber dari Maturity IPAF (ITIL Process Assessment Framework).

Perspektif Kematangan Proses: Teknik Self Assessment, Memberikan indikasi dari pandangan praktisi IT, seberapa baik proses telah dikerahkan dan dieksekusi

Deskripsi Maturity Level pada IT-IL [8] adalah sebagai berikut:

0 : Non-existent, Nothing present

1: Initial, No standard Processes, Ad hoc

approaches.

2: Repeatable, No formal training or

communication.

3: Defined, Standarized and documented.

4: Manage, Monitor and measure compliance to procedures.

5: Optimized, Proactive and continues self improvement.

\subsection{Fase 5 Penelitian}

IT IL - Service Level Management SLA and KPI. Laporan kematangan proses bisnis dan saran yang diberikan kepada perusahaan, berupa proses bisnis yang kurang optimal atau proses bisnis baru yang dianggap perlu muncul sesuai standar eTOM.

\subsection{Pengujian Sistem}

Uji tabulasi hasil pengambilan data kuesioner terdiri dari uji validitas dan uji realibilitas. Uji validitas untuk mengetahui kelayakan butir-butir pertanyaan yang diajukan dalam kuesioner, sedangkan uji realibilitas melihat konsistensi/kehandalan jawaban kuesioner.

\subsubsection{Uji Validitas}

Menggunakan korelasi Bevariate Pearson untuk uji validitas data, dengan mengkorelasikan masingmasing skor item pertanyaan dengan skor total. Berikut adalah hipotesis dalam pengujian validitas:

Ho: Jika nilai rhitung > rtabel, maka item pertanyaan atau pernyataan dalam angket berkorelasi signifikan terhadap skor total (artinya item kuesioner dinyatakan valid). 
Ha: Jika nilai rhitung < rtabel, maka item pertanyaan atau pernyataan dalam angket tidak berkorelasi signifikan terhadap skor total (artinya item kuesioner dinyatakan tidak valid).

\subsubsection{Uji Realibilitas}

Menggunakan rumus cronbach alpha untuk uji reliabilitas. Berikut hipotesis pengujian realibilitas:

Ho: Jika nilai Cronbach Alpha $>0,60$, maka konstruk atau variabel dikatakan reliabel (artinya kuesioner dinyatakan realibel).

Ha: Jika nilai Cronbach Alpha $<0,60$, maka konstruk atau variabel dikatakan tidak reliabel (artinya kuesioner dinyatakan tidak realibel).

\subsection{Hasil Uji Validtas dan Realibilitas}

Pada pengolahan data pertama, didapatkan proses bisnis SCIM dan SPH memenuhi syarat validitas dan realibilitas, sedangkan tiga proses lainya $\mathrm{SOH}$, SCQ, MCI memerlukan percobaan lanjutan.

Tabel 2. Hasil Uji Validitas dan Realibilitas

\begin{tabular}{lccc}
\hline \multirow{2}{*}{ Proses Bisnis } & \multicolumn{3}{c}{ Pengolahan Data Pertama } \\
\cline { 2 - 4 } & $\begin{array}{l}\text { Validitas } \\
\text { pearson }\end{array}$ & $\begin{array}{c}\text { Reliabilitas } \\
\text { Cronbach }\end{array}$ & $\begin{array}{c}\text { Butir } \\
\text { Valid }\end{array}$ \\
\hline $\begin{array}{l}\text { Support Customer } \\
\text { Interface Mgt } \\
\text { (SCIM) }\end{array}$ & Ya & Ya & $\underline{\mathbf{1 5}}$ \\
\hline $\begin{array}{l}\text { Support Order } \\
\text { Handling (SOH) }\end{array}$ & $\mathrm{Ya}$ & $\mathrm{Ya}$ & $\underline{\mathbf{1 1}}$ \\
\hline $\begin{array}{l}\text { Support Problem } \\
\text { Handling (SPH) }\end{array}$ & $\mathrm{Ya}$ & $\mathrm{Ya}$ & $\underline{\mathbf{1 4}}$ \\
\hline $\begin{array}{l}\text { Support Customer } \\
\text { QoS/SLA (SCQ) }\end{array}$ & $\mathrm{Ya}$ & $\mathrm{Ya}$ & $\underline{\mathbf{1 4}}$ \\
\hline $\begin{array}{l}\text { Manage Customer } \\
\text { Inventory (MCI) }\end{array}$ & $\mathrm{Ya}$ & $\mathrm{Ya}$ & $\underline{\mathbf{9}}$ \\
\hline
\end{tabular}

\subsection{Tingkat Kematangan Proses Bisnis}

Tingkat Kematangan atribut dihitung dengan menggunakan rumus rata-rata, yaitu total bobot jawaban kuesioner dibagi dengan jumlah pertanyaan.

Distribusi skor proses bisnis 1: Support Customer Interface Management - SCIM \begin{tabular}{|l|l|l|l|l|l|l|l|l|l|l|l|l|l|l|l|}
\hline Pertanyaan & Q1 & Q3 & 05 & Q6 & Q7 & Q8 & Q9 & Q10 & Q12 & Q13 & Q14 & Q15 & Q16 & Q18 & Q19 \\
\hline
\end{tabular} \begin{tabular}{|l|r|r|r|r|r|r|l|l|l|l|l|l|l|l|l|}
\hline Ratar-rata & 3.6 & 3.44 & 3.56 & 4.08 & 4.04 & 3.76 & 4.16 & 3.76 & 3.92 & 3.6 & 2.84 & 4.12 & 3.36 & 3.16 & 3 \\
\hline
\end{tabular} Didapatkan rata-rata level kematangan di tingkat 3,63

Distribusi skor proses bisnis 2: Support Order Handling - $\mathrm{SOH}$

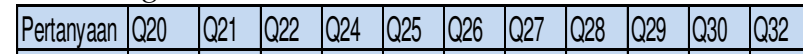

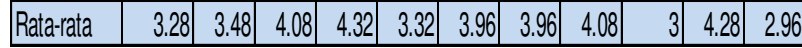
Didapatkan rata-rata level kematangan di tingkat 3.7
Distribusi skor proses bisnis 3: Support Problem Handling - SPH

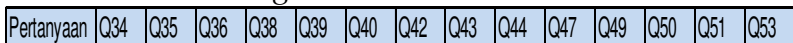
\begin{tabular}{l|l|l|l|l|l|lllllllll}
\hline Ratar-rata & 3.6 & 4.56 & 3.6 & 4.28 & 3.88 & 3.88 & 2.84 & 3.52 & 2.8 & 2.4 & 4.52 & 3.84 & 3.92 & 3.4 \\
\hline
\end{tabular} Didapatkan rata-rata level kematangan di tingkat 3.65

Distribusi skor proses bisnis 4: Support Customer QoS/SLA - SCQ

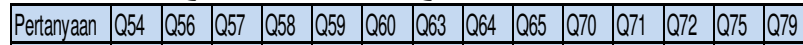

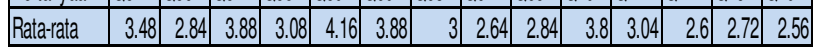

Didapatkan rata-rata level kematangan di tingkat 3,18

Distribusi skor proses bisnis 5: Manage Customer Inventory - MCI

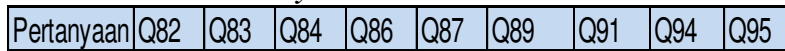
\begin{tabular}{|l|l|l|l|l|l|l|l|l|l|}
\hline Rata-rata & 2.88 & 2.32 & 3.4 & 2.92 & 3.04 & 3.92 & 4.04 & 3.32 & 2.72 \\
\hline
\end{tabular} Didapatkan rata-rata level kematangan di tingkat 3.17

\section{Analisis dan Hasil Penelitian}

Dari hasil pengolahan data didapatkan rata-rata skor pertanyaan valid, sebagai tingkat kematangan proses bisnis saat ini (as-is). Sedangkan tingkat kematangan yang akan dicapai adalah nilai standar "Framework eTOM Assurance CRM" proses bisnis terkait.

Tabel 3 : Tingkat kematangan Proses Bisnis

\begin{tabular}{llc}
\hline \multirow{1}{*}{ Proses Bisnis } & \multicolumn{2}{c}{$\begin{array}{c}\text { Tingkat } \\
\text { Kematangan }\end{array}$} \\
\cline { 2 - 3 } & as-is & to-be \\
\hline $\begin{array}{l}\text { Support Customer Interface } \\
\text { Management } \text { - SCIM }\end{array}$ & 3.63 & 4 \\
\hline $\begin{array}{l}\text { Support Order Handling - SOH } \\
\text { Support Problem Handling - SPH }\end{array}$ & 3.70 & 4 \\
\hline $\begin{array}{l}\text { Support Customer QoS/SLA - } \\
\text { SCQ }\end{array}$ & 3.18 & 4 \\
\hline $\begin{array}{l}\text { Manage Customer Inventory - } \\
\text { MCI }\end{array}$ & 3.17 & 4 \\
\hline
\end{tabular}

\subsection{Analisa Tingkat Kematangan Saat Ini}

Indikasi $80 \%$ tingkat kematangan saat ini $>3$ (terdefinisi), maka kebutuhan akan Management CRM telah dipahami dalam organisasi. Walaupun organisasi belum mencapai kematangan standar eTOM.

Indikasi Proses bisnis Support Problem Handling memiliki tingkat kematangan tertinggi 3,9, maka Organisasi CRM telah memahami tentang aturan, prinsip dan konsep dasar dari Order/Pemesanan layanan oleh pelanggan. Pelatihan IT informal telah dilakukan secara baik, melalui praktik langsung. 
Indikasi Proses bisnis Support Customer QoS/SLA memiliki tingkat kematangan terendah dalam organisasi, maka Organisasi CRM belum memanfaatkan Aplikasi CRM, untuk mendukung tercapainya QoS / SLA. Belum adanya proses yang proaktif memantau dan menilai kinerja terhadap parameter QoS / SLA. Adanya kekurangan dalam manajemen dan pelaporan, terhadap kemampuan proses mencapai QoS / SLA. Menurut indikasi hasil borang pada proses bisnis Support Customer QoS/SLA yang memiliki level kematangan terendah

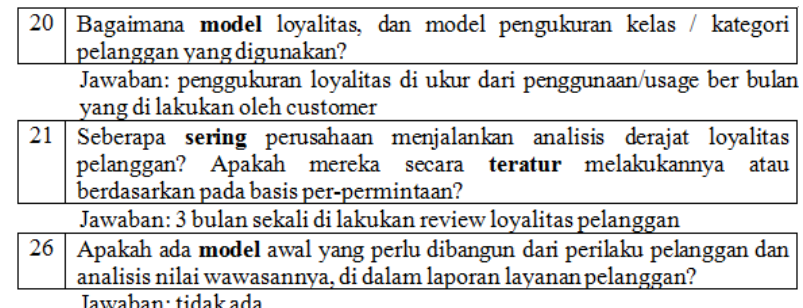

Gambar 11. Hasil Borang Penelitian

Berdasarkan borang ditemukan kekurangan sebagai berikut: Review loyalitas dilakukan dalam waktu yang terlalu lama, Parameter loyalitas yang diukur sangat terbatas hanya pada usage/penggunaan, Prosedur Management data belum didokumentasikan secara menyeluruh karena tidak ada model.

\subsection{Analisa Tingkat Kematangan yang Diharapkan}

Tingkat kematangan proses bisnis yang ingin dicapai adalah mengacu pada proses bisnis CRM kerangka eTOM pada subproses terkait. Keempat proses bisnis tersebut, pada kerangka eTOM memiliki tingkat kematangan bernilai 4 (Managed).Kematangan tingkat 4 IT-IL: Terukur dan terkontrol, yaitu terdapat kumpulan data dan proses rinci dengan kualitas baik.

Analisa TO-BE (Operations - Assurance) menurut eTOM sesuai kematangan tingkat 4 eTOM CRM adalah proses bisnis telah memiliki kriteria berikut: Create Customer Problem Report, Correct \& Recover Customer Problem, Track \& Manage Customer Problem, Report Customer Problem, Close Customer Problem Report, Isolate Customer Problem.

\subsection{Analisa Kesenjangan (Gap)}

Menganalisa kesenjangan antara aktual proses bisnis saat ini terhadap eTOM, maka melalui kesenjangan atribut Support Customer Interface Management, Support Order Handling dan Manage Customer Inventory adalah relatif sama sebesar 0.5 s/d 0.6, dan Support Customer QOS/SLA memiliki kesenjangan terbesar yaitu 1 tingkat. Adapun Support Problem Handling dianggap tidak memiliki kesenjangan karena hanya memiliki selisih kecil 0.1.

Berdasarkan standar proses bisnis eTOM yang menjadi acuan, maka semua atribut diharapkan mencapai kematangan level 4. Perlu adanya perbaikan berupa proses pencapaian tingkat kematangan level 4 pada Support Customer QoS/SLA berdasarkan Framework eTOM Assurance CRM.

\subsection{Pencapaian Tingkat Kematangan 4}

Terdapat enam kriteria mencapai level kematangan eTOM "Support Customer QOS/SLA - SCQ", yang perlu diterapkan pada organisasi CRM operator, sesuai Framework eTOM Assurance CRM.

1. Access Customer QOS/SLA Performance. Mengelola keseluruhan penilaian kinerja QOS/SLA pelanggan dan Melakukan pemantauan proaktif

2. Create Customer QOS Performance Degradation Report. Membuat laporan yang menilai kinerja QOS yang menurun

3. Manage QOS/SLA violation. Memastikan pelanggan dan proses internal terkait mendapatkan informasi yang cukup

4. Track \& Manage Customer QOS performance resolution. Secara efisien Menunjuk, mengkordinasikan dan menelusuri pelanggan yang membeli produk.

5. Report Customer QoS Performance. Analisis agregat kinerja QoS seluruh kelompok pelanggan atau analisis jenis SLA, melacak dan memantau proses QoS/SLA Pelanggan dan biaya yang terkait, dan melaporkannya sebagai kemampuan pelanggan dalam memproses QoS/SLA

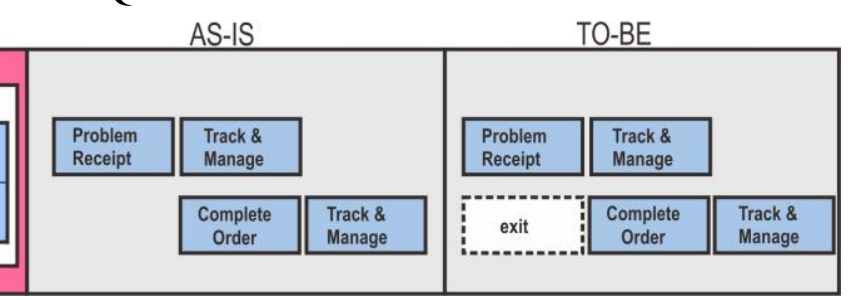

Gambar 12. Analisis TO-BE eTOM (Operations-Assurance)

\begin{tabular}{|c|c|c|c|c|c|c|c|c|c|c|}
\hline \multirow{2}{*}{ CRM } & OSR & \multicolumn{3}{|c|}{ Assurance } & \multicolumn{3}{|c|}{ AS-IS } & \multicolumn{3}{|c|}{ TO-BE } \\
\hline & & Customer Proble & tandling & & & & & & & \\
\hline & \begin{tabular}{|} 
Support \& Readiness \\
Support Customer
\end{tabular} & $\begin{array}{l}\text { Create Customer } \\
\text { Problem Report }\end{array}$ & $\begin{array}{l}\text { Correct \& Recover } \\
\text { Customer Problem }\end{array}$ & $\begin{array}{c}\text { Track \& Manage } \\
\text { Customer Problem }\end{array}$ & $\begin{array}{l}\begin{array}{l}\text { Problem } \\
\text { Receipt }\end{array} \\
\text { R }\end{array}$ & $\begin{array}{l}\text { Track \& } \\
\text { Manage }\end{array}$ & & $\begin{array}{l}\begin{array}{l}\text { Problem } \\
\text { Receipt }\end{array} \\
\end{array}$ & 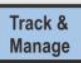 & \\
\hline & \begin{tabular}{|c|} 
Manage Customer \\
Inventory
\end{tabular} & $\begin{array}{c}\text { Report Customer } \\
\text { Problem }\end{array}$ & $\begin{array}{l}\text { Close Customer } \\
\text { Problem Report }\end{array}$ & $\begin{array}{c}\text { Isolate Customer } \\
\text { Problem }\end{array}$ & & $\begin{array}{c}\text { Complete } \\
\text { Order }\end{array}$ & $\begin{array}{l}\text { Track \& } \\
\text { Manage }\end{array}$ & exit & $\begin{array}{l}\text { Complete } \\
\text { Order }\end{array}$ & $\begin{array}{l}\text { Track \& } \\
\text { Manage }\end{array}$ \\
\hline
\end{tabular}


6. Close Customer QoS performance Degradation Report. Menutup laporan penurunan kinerja QOS, tepat saat masalah telah diselesaikan

\section{Kesimpulan}

Penelitian mengidentifikasi faktor atau aspek potensial pada perusahaan operator yang akan dialihdayakan melalui Manage service, yaitu dalam unit bisnis Customer Relationship Management. eTOM digunakan untuk mendefinisikan proses bisnis beserta kriteria pendukungnya, dalam organisasi CRM - Customer Care. Aspek faktor atau potensial perusahaan diidentifikasi melalui komponen proses bisnis framework eTOM, untuk kemudian dipetakan pada proses bisnis Customer Care, dimana didapatkan 5 dari 16 proses bisnis hasil identifikasi: Support Customer Interface Management, Support Order Handling, Support Problem Handling, Support Customer QOS/SLA, Manage Customer Inventory.

Restrukturisasi atau perancangan tata kelola Manage service pada organisasi perusahaan mampu dilakukan melalui evaluasi Level kematangan IT-IL, dengan mengetahui proses bisnis saat ini saat ini (as-is) dan kondisi yang diharapkan (to-be). Mengetahui kondisi yang dapat diharapkan dalam rangka penglihdayaan unit bisnis melalui Manage service, dengan melakukan evaluasi maka proses bisnis yang sudah baik dapat dipertahakankan, sedangkan proses bisnis yang kurang atau tidak baik dapat dilakukan perbaikan berdasarkan kondisi yang diharapkan. Menerapkan Service Level Management (SLM) pada unit kerja Customer Relationship Management - Customer Care, dengan output berupa matriks tanggungjawab RACI dan dokumen KPI (Key Performance Indicator)

Pengaruh framework eTOM dan IT-IL terhadap desain Manage service, sesuai evaluasi yang telah dilakukan. Organisasi CRM pada operator yang diteliti saat ini (as is) berdasarkan framework eTOM dan IT-IL secara umum sudah baik dikarenakan memiliki tingkat kematangan yang hampir mencapai standar nilai kematangan eTOM. Yaitu pada 3 proses bisnis yaitu: Support Customer Interface Management, Support Order Handling, dan Manage Customer Inventory. Karena sudah cukup baik dengan level kematangan (3.6 - 3.7), maka Manage service tetap dapat menggunakan mekanisme proses bisnis yang sedang berlaku saat ini tanpa melakukan perubahan signifikan.
Tingkat kematangan proses bisnis Support Order Handling, memiliki level tertinggi yaitu 3.7, nilai tersebut hamper mendekati level kematangan tertinggi eTOM pada proses bisnis yang sama. Pengalihdayaan melalui Manage service tanpa perlu melakukan perubahan mekanisme proses bisnis yang telah berlaku saat ini.

\section{Daftar Pustaka}

[1] Arrianto MW, IT Governance Maturity At Indonesian State Owned Enterprises:Contingent Factors \& Impacts, Universitas Indonesia, Jakarta2011.

[2] Francesco L, Outsourcing Of Manage Tellecomunication Services: Reasons and Implications on Service Development and Business Model, Politecnico di Milano, Milan, 2011.

[3] Hou J, A Practical Approach to the Operation of Telecommunication Services driven by the TMF eTOM Framework, Universitat Politècnica de Catalunya, Barcelona Spain, 2009.

[4] Jenny H, "eTOM and ITIL - An IT Outsourcing Service Provider", BPTrends Journal eTOM and ITIL,2005.

[5] Kannamani, Effective Implementation of Problem Management in ITIL Service Management, International Journal of Scientific \& Engineering Research, Houston USA, 2013.

[6] Nontobeko, Investigating The Use of The ITIL Framework Towards IT Service Delivery, NMMU, South Africa, 2009.

[7] OGC, ITIL V3 - Service Design, TSO for OGC, United Kingdom, 2011.

[8] Peter AJ, Information Technology Infrastructure Library Problem-A Maturity Model Approach, Boise State University, Idaho United States, 2009.

[9] Peter L, Manage service in Telecommunication Sector Getting messages across, Gavle University, Swedia, 2008.

[10] Raninditha, Aplikasi Manage services Pada Operator Telekomunikasi, (XL Axiata) dan operator jaringan (PT Huawei), Universitas Indonesia, Jakarta, 2012.

[11] TM Forum, Business Process Framework eTOM v12, TM Forum, USA, 2012.

[12] Nimmy J, Integrating the eTOM Business Process Framework into the Ericsson Seamless Modeling, Technische Universiteit Eindhoven, Belanda, 2010

[13] Faride L, Enriched eTOM Framework in Service Deliver Operation through Alignment with COBIT5 Strategic Objectives, Islamic Azad University, Iran, 2014.

[14] Mursyid H, Rute Menuju Best Practice, SBM ITB, Bandung, 2008.

[15] Sugiyono, Metode Penelitian Administrasi, Alfabeta, Bandung, 2001. 
